\title{
Chapter 4 \\ Impact of Intellectual Capital on the Organizational Performance of Airline Industry in Malaysia
}

\author{
Muhammad Khalique \\ Universiti Malaysia Sarawak, Malaysia \\ Abu Hassan Md. Isa \\ Universiti Malaysia Sarawak, Malaysia
}

\begin{abstract}
This chapter aims to examine the role of intellectual capital in order to enhance the organizational performance of airline industry in Malaysia. Five components of intellectual capital, namely human capital, customer capital, structural capital, technological capital, and spiritual capital, were used to investigate the role of intellectual capital in airline industry in Malaysia. A structured questionnaire was used to gather the required data from Kuala Lumpur, Sultan Ismail Johor Bharu International Airport, and Kuching International Airport. A total of 195 out of 200 useable questionnaires were collected. Multiple regression analysis was employed to test the proposed research hypotheses of this study. The findings show that two variables, namely customer capital and spiritual capital, appeared as significant contributors while the remaining three variables, human capital, structural capital, and technological capital, appeared as insignificant contributors. This is a preliminary study and it could be a milestone for further studies.
\end{abstract}

\section{INTRODUCTION}

Current research has shown that intellectual capital has been appeared to be the most crucial strategic asset for the success of an organization. To stay in a competitive environment every organization is trying to explore and capitalize their soft assets to fix the global challenges. In a knowledge-based economy, organizations are facing multifarious and complex challenges to get the competitive edge. More specifically, high-tech industries are facing serious threats and opportunities in a competitive environment. Moreover, the overwhelming demand of knowledge-based products and services is shaping the new competitive business environment. Competitive edge is a prime concern

DOI: $10.4018 / 978-1-4666-7470-7 . c h 004$ 
of all high-tech and services oriented industries. Many organizations believe that intellectual capital management has a pivotal role to enhance their organizational performance and sustainability.

Intellectual capital measurement and management is a foundation of the development of new business models that helps the organization to mobilize intangible assets and knowledge resources to be more creative, innovative and proactive enterprises. The management and the assessment of knowledge assets support the domination of an organization not only by improving the strategy planning, but also affect the organizational behavior. Intellectual capital management helps the entrepreneurs, key position holders such as directors, chief executives, general managers, and managers to learn from experience in different contexts. For example, in terms of size, industry, location, and nature of industry and so on, firms need to identify and adopt the best possible business solutions to fix the challenges and threats.

Many researchers such as (Abdel-Aziz, Abdul-Naser, \& Nasser, 2013; Bontis, Keow, \& Richardson, 2000; Muhammad Khalique, 2012; Muhammad Khalique, Shaari, Isa, \& Samad, 2013) argued that intellectual capital is a crucial asset for the success and sustainability of organizations in a knowledge based economy. Muhammad Khalique (2012) and (Muhamamd Khalique, Shaari, \& Isa, 2013) stressed that intellectual capital is a most important strategic asset for the success of the organization. Moreover, they emphasized that in a knowledge-based economy it is indispensible for the high-tech or knowledge intensive organizations to explore, manage and capitalize their intellectual capital in order to stay in a competitive environment because without this crucial asset there is limited chance for the organization to survive in business environment.

Despite the significant contribution of intellectual capital in enhancing the performance of organizations its understanding and applications in many organizations such as transport industry is still at preliminary stage, particularly in Ma- laysia. Hamzah and Mohamed (2010) conducted their study in an airline sector in Malaysia. They highlighted the concept and the application of intellectual capital having three components namely, human capital, customer capital and structural capital by using the secondary data. They argued that technological based and a service industry such as the airline industry is facing new threats and opportunities. Physical assets such as terminals, aircrafts, and equipments always create value for industry but now the scenario has changed. Nowadays the customers are more concerned about value added products and services. However, in the related literature reviewed it was found that there is no study available to highlight the importance of intellectual capital with holistic approach in the airline sector in Malaysia. Undoubtfully the transport industry is one of major players in an economy and social structure. This preliminary study employed five components of intellectual capital namely, human capital, customer capital, structural capital, technological capital and spiritual capital, and it focuses on the airline sector in Malaysia.

\section{INTELLECTUAL CAPITAL}

Fundamentally, intellectual capital represents the soft assets of the organization that will help to create value added products and services. The ultimate goal is to satisfy the customer's needs and improve their lifestyles. The term intellectual capital was introduced by John Kenneth Galbraith in 1969 and argued that intellectual capital represents more than just "intellect as pure intellect" (Feiwal, 1975). Many researchers such as (Bontis, 1998; Cabrita, 2009; Castro \& Delgado-Verde, 2012; Khalique, Mansor, Isa, \& Shaari, 2014; Kujansivu, 2009; Stewart, 1997; Subramaniam \& Youndt, 2005) define the concept of intellectual capital according to their own intellectual capital classification on the basis of their research subjects and objectives. Mostly they argue that intellectual 